University of Nebraska - Lincoln

DigitalCommons@University of Nebraska - Lincoln

2012

\title{
Hydrated lime for metals immobilization and explosives transformation: Treatability study
}

W. Andy Martin

US Army Corps of Engineers, andy.martin@usace.army.mil

S.L. Larson

US Army Corps of Engineers

C.C. Nestler

Applied Research Associates, Inc.

G. Fabian

US Army Aberdeen Test Center

G. O'Connor

US Army RDECOM-ARDEC

See next page for additional authors

Follow this and additional works at: https://digitalcommons.unl.edu/usarmyresearch

Martin, W. Andy; Larson, S.L.; Nestler, C.C.; Fabian, G.; O'Connor, G.; and Felt, Deborah R., "Hydrated lime for metals immobilization and explosives transformation: Treatability study" (2012). US Army Research. 206.

https://digitalcommons.unl.edu/usarmyresearch/206

This Article is brought to you for free and open access by the U.S. Department of Defense at DigitalCommons@University of Nebraska - Lincoln. It has been accepted for inclusion in US Army Research by an authorized administrator of DigitalCommons@University of Nebraska - Lincoln. 


\section{Authors}

W. Andy Martin, S.L. Larson, C.C. Nestler, G. Fabian, G. O'Connor, and Deborah R. Felt 


\title{
Hydrated lime for metals immobilization and explosives transformation: Treatability study
}

\author{
W. Andy Martin a,*, S.L. Larson ${ }^{\mathrm{a}}$, C.C. Nestler ${ }^{\mathrm{b}}$, G. Fabian ${ }^{\mathrm{c}}$, G. O’Connor ${ }^{\mathrm{d}}$, D.R. Felt ${ }^{\mathrm{a}}$ \\ a US Army Corps of Engineers, Engineer Research and Development Center, Vicksburg, MS 39180, USA \\ b Applied Research Associates, Inc., Vicksburg, MS 39180, USA \\ c US Army Aberdeen Test Center, Aberdeen Proving Ground, MD 21005, USA \\ ' US Army RDECOM-ARDEC, Picatinny, NJ 07806, USA
}

\section{A R T I C L E I N F O}

\section{Article history:}

Received 14 December 2011

Received in revised form 22 February 2012

Accepted 25 February 2012

Available online 3 March 2012

\section{Keywords:}

Hand grenade range

Hydrated lime

Munitions constituents

Range management

Best management practice

\begin{abstract}
A B S T R A C T
Fragmentation grenades contain Composition B (RDX and TNT) within a steel shell casing. There is the potential for off-site migration of high explosives and metals from hand grenade training ranges by transport in surface water and subsurface transport in leachate. This treatability study used bench-scale columns and mesocosm-scale laboratory lysimeters to investigate the potential of hydrated lime as a soil amendment for in situ remediation of explosives and metals stabilization in hand grenade range soils. Compared to the unamended soil there was a 26-92\% reduction of RDX in the leachate and runoff water from the lime treated soils and a $66-83 \%$ reduction of zinc in the leachate and runoff water samples; where the hand grenade range metals of concern were zinc, iron, and manganese. The amended soil was maintained at the target $\mathrm{pH}$ of greater than 10.5 for optimum explosives decomposition. The treatability study indicated a high potential of success for scale-up to an in situ field study.
\end{abstract}

Published by Elsevier B.V.

\section{Introduction}

The treatability study was performed using soil from a fixed position hand grenade range (HGR). Fragmentation grenades are the primary source of munitions constituents at this type of range. The grenades are typically composed of Composition B explosive material encased in a steel shell. Composition $B$ is a 60:39:1 percent by weight mixture of hexahydro-1,3,5-trinitro-1,3,5-triazine (RDX), 2,4,6-trinitrotoluene (TNT), and wax binder; respectively. RDX has been found on HGRs at concentrations ranging from less than 0.01 (at the detection limit) to $51 \mathrm{mg} / \mathrm{kg}$ [ $n=13$ ]; where ' $n$ ' is the number of analyzed samples [1]. The fate and transport process descriptors for explosives in soil and water have shown that RDX has a low soil adsorption potential for most soils [2]. The limited sorption, along with the potentially high magnitude of contamination at many sites, leads to a high potential of migration and contamination of groundwater [3-5].

The fate of metals in soils depends on the physical and chemical properties of both the specific metal and the soil conditions. Metals found on HGRs occur in the form of discrete particles (intact munitions or fragments), as well as metal salts (weathering

\footnotetext{
* Corresponding author. Tel.: +1 6016343710; fax: +1 6016343518

E-mail addresses: Andy.Martin@usace.army.mil (W.A. Martin), Deborah.Felt@usace.army.mil (D.R. Felt).
}

products) and dissolved metal or metallic complexes adsorbed to the soil matrix [6-8]. Transport off-range, via surface water runoff and/or leachate, is more likely when the metals are in a soluble form for instance at low $\mathrm{pH}$ levels. Significant downward migration of metals from the soil surface can also occur when the metal retention capacity of the soil is exceeded. The capacity of soil to adsorb $\mathrm{Pb}$ and $\mathrm{Zn}$ increases with increased $\mathrm{pH}$ levels. Controlling soil and pore water $\mathrm{pH}$ can, therefore, directly impact the fate and transport of metals associated with munitions constituents $[9,10]$. Metals are not degraded or easily detoxified. The most commonly used treatment technologies for metals in soils on firing ranges include solidification/stabilization, excavation and offsite disposal, and acid extraction [10,11].

The use of the alkaline hydrolysis reaction as a means to degrade various environmental contaminants is reviewed in the USEPA report on Fate, Transport, and Transformation Test Guidelines [12], and the National Research Council [13]. Alkaline hydrolysis decomposes the explosives, including RDX, to organic and inorganic salts, soluble organic compounds, and various gases; it depends on bringing the explosive into direct contact with the hydroxide ion, a reaction which takes place within the soil pore water and following alkaline hydrolysis biodegradation can occur with additional reduction of the decomposition byproducts [14-17]. The alkaline hydrolysis reaction removed nitroaromatics and nitramines from a variety of different soil types, although the reaction rate was slower in soils with high clay content (i.e., high 


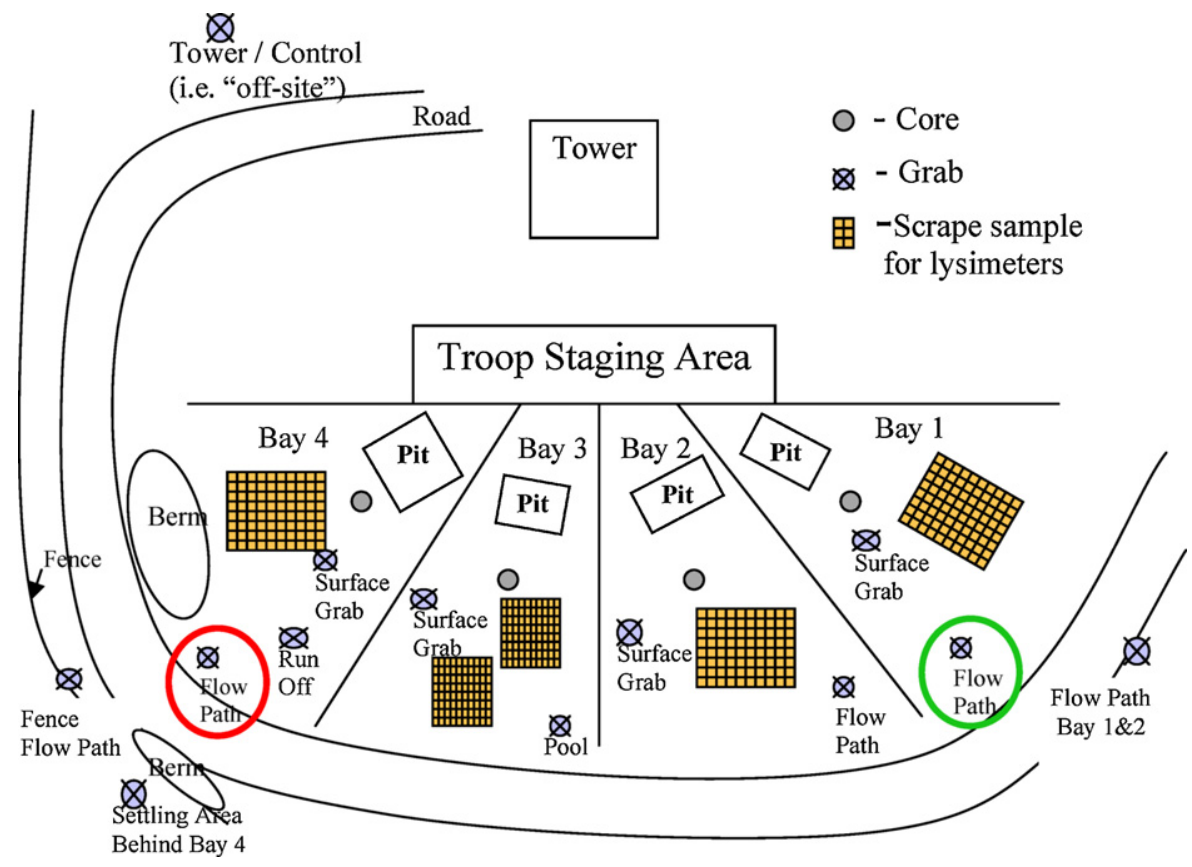

Fig. 1. Schematic of the hand grenade range.

cation exchange capacity, CEC). At pilot-scale, the reaction performed best when the lime was mixed well into the soil, bringing the hydroxide ion into close contact with the explosive material. The calcitic, hydrated lime $\left(\mathrm{Ca}(\mathrm{OH})_{2}\right)$, used primarily in engineering applications, proved most amenable to soil treatment for alkaline hydrolysis $[17,18]$.

Munitions constituents are also potential sources for soil and water contamination by heavy metals. The addition of lime has been used to treat heavy metals contamination in a variety of applications: wastewater treatment $[19,20]$, treatment of sewage sludge solids [21,22], and treatment of contaminated soils and sediments [23-25]. These authors reported a decrease in soluble and extractable metals concentrations in the lime-treated soil [19-25]. Geebelen et al. [24] reported that alkaline hydrolysis of metalscontaminated soil decreased the phytotoxicity, plant $\mathrm{Pb}$ uptake, allowed re-vegetation of the soil, and passed the microbiological sensor test.

The development of effective treatment options for energetic and heavy metal contaminants is essential for HGR best management practice (BMP) and sustainability [26-29]. The column and lysimeter treatability studies were undertaken to define the parameters necessary to scale-up the lime treatment technology from the laboratory to the field. Lime treatment (alkaline hydrolysis) has the potential to transform high explosives (HE) and stabilize metal residues in range soil, preserving the environment, range longevity, and prevent transport of the energetics and metals into the surface and groundwater resources.

\section{Experimental}

The soil used in the treatability studies was obtained from an active HGR in the Southeastern USA (Fig. 1). This is a 4-bay training range that uses the local sandy clay soil as the impact area. Each bay is separated by vegetated, earthen berms approximately $80 \mathrm{~m}$ long and $5 \mathrm{~m}$ tall. The ranges' four throwing bays are typically operated five (5) days a week throughout the year with a consistent throw rate of grenades in each bay per day.

\subsection{Soil collection and preparation}

Soil was obtained from around the target placements in the throwing bays (Bays 1 through 4). Soil to be used as a background reference was obtained from an off-site area southeast of the observation tower. The soils were transported to the U.S. Army Engineer Research and Development Center, Environmental Laboratory (ERDC-EL) (Vicksburg, MS) in 55-gal, polyethylene-lined drums. A composite sample was made from each of the Bay 2 and Bay 4 drums by, first, air-drying the soil. A large polyethylene-lined box was used for a 12-step "combining and halving" soil homogenization process employing shovels, rakes, and a small tiller. Large rocks $(>5 \mathrm{~cm})$ and organic debris (sticks and root mats $>200 \mathrm{~cm}^{3}$ ) were removed during the homogenization process. Based on earlier research this homogenization process reduces the contaminant heterogeneity to a large extent and it has been shown to result in a $21 \%$ relative standard deviation (RSD) for the chemical analysis, based on 9 replicates [6]. Soil was weighed and stored in 55-gal, polyethylene-lined drums before being used in the treatability studies. Nine sub-samples of the newly mixed soil were collected for initial explosives and metals analysis. Representative aliquots of the soils were subjected to soil characterization that included soil $\mathrm{pH}$, particle-size distribution, total organic carbon (TOC), and cation exchange capacity (CEC).

\subsection{Bench-scale column study}

An environmental concern associated with the use of hydrated lime for the amendment of range soils has been the potential for increased alkalinity of leachate (pore water) and groundwater. A column study evaluated the effect of liming on leachate $\mathrm{pH}$ as a function of distance from the lime treatment zone. The operating conditions for both the column study and the lysimeter study are outlined in Table 1. The column assembly is shown in Fig. 2. HGR soil $(7.62 \mathrm{~cm}, 300 \mathrm{~g}$ ) was mixed with three (3)-g of hydrated lime and placed on top of 7.62-cm of native soil inside a $5.08-\mathrm{cm}$ (ID) column. Two additional 5.08-cm ID columns were packed with $15.24-\mathrm{cm}$ of native soil and were set in series for a total soil depth of $45.72-\mathrm{cm}$. The annual rainfall of the base in the Southeast USA was simulated 
Table 1

Operating conditions for the HGR soil column and lysimeter treatability studies.

\begin{tabular}{llll}
\hline Experimental condition & Columns & \multicolumn{2}{l}{ Lysimeters } \\
\hline RDX - initial concentration & $2.38 \mathrm{mg} / \mathrm{kg}$ & All cells $-2.38 \mathrm{mg} / \mathrm{kg}$ \\
Lime amendment (\%) & $1 \%$ & Cell 1 & $0 \%$ (control) \\
& & Cell 2 & $0.50 \%$ \\
& & Cell 3 & $1 \%$ \\
RO water per wetting event & $160-\mathrm{mL}$ & Cell 4 & $2 \%$ \\
\hline
\end{tabular}

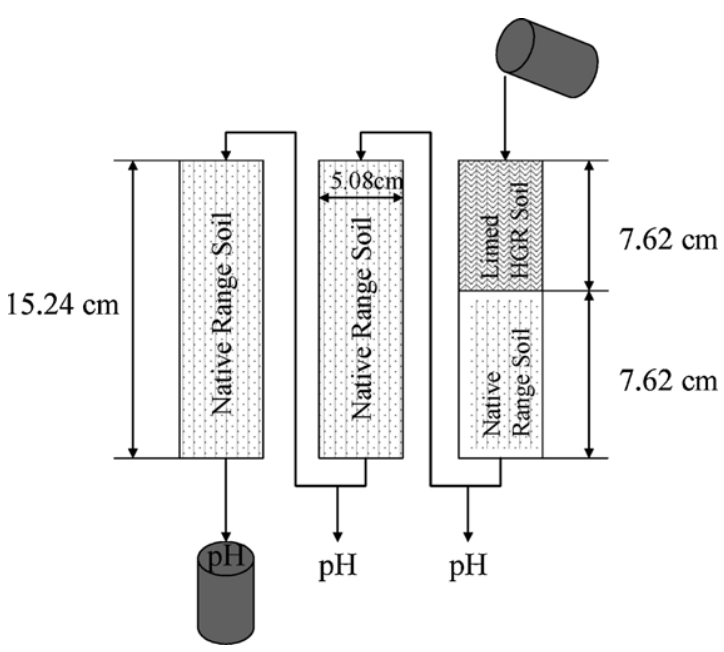

Fig. 2. Schematic of the column study.

using reverse osmosis (RO) water, $\mathrm{pH}$ 6.6, in seven weekly wetting events. At each event, $160-\mathrm{mL}$ of RO water was added to Column 1 and leachate samples were collected for $\mathrm{pH}$ analysis at the 15.24-, 30.48-, and 45.72-cm depths; the leachate was collected over six days and approximately 125-, 95-, and $85 \mathrm{~mL}$ was collected at each depth, respectively.

\subsection{Mesoscale lysimeter study}

The mesocosm lysimeters were designed [7] to allow for the collection of leachate flowing through the soil as well as runoff from the soil surface (Fig. 3). The lysimeters were constructed from 1.91-cm-thick, high-density polyethylene that measured $0.79 \mathrm{~m} \times 0.79 \mathrm{~m} \times 0.61 \mathrm{~m}$ (inside length $\times$ width $\times$ height). The lysimeters were placed on stands constructed from angle iron, with a $1-2^{\circ}$ slope for collection of surface water runoff. Sufficient room remained above the soil mixture for a portion of the simulated rain to puddle and flow through the runoff trough into the runoff collection system (Fig. 3). Leachate and runoff waters were collected in polyethylene pans. All tubing in the collection system was made from non-reactive silicone or polyethylene.

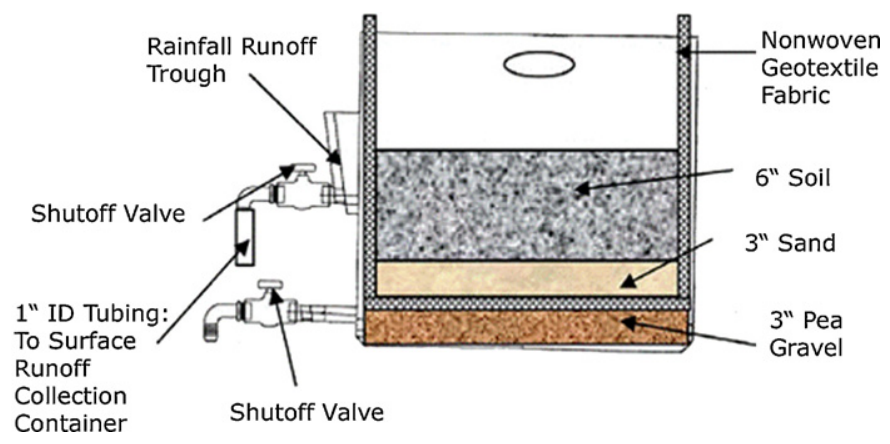

Fig. 3. Cross section schematic of a mesoscale laboratory lysimeter.
Three inches (7.62-cm) of pea gravel was placed on the bottom of the lysimeter to prevent the sediment from clogging the exit tubes during the weekly rainfall event (Fig. 3). A layer of non-woven geotextile was placed on the pea gravel and draped around the inside of the lysimeter. A layer of coarse sand was placed on the geotextile and compacted to $7.62 \mathrm{~cm}$. The total soil volume from the site was divided into equal parts for the appropriate number of lysimeters. The soil sub-samples were weighed and mixed in a rotary cement mixer for $15 \mathrm{~min}$ with the appropriate amount of hydrated lime (Table 1 ). For each lysimeter, approximately $200-\mathrm{kg}$ of the HGR soil was placed in three $5-\mathrm{cm}$ increments over the sand layer. The test soils were compacted to form a soil layer approximately $15.24 \mathrm{~cm}$ deep. The control was non-limed HGR soil.

Rainfall simulators [7] were constructed from clear Plexiglas boxes and rested on mobile carts directly above the lysimeters. A water reservoir containing $\mathrm{RO}$ water was placed above each rain simulator box. Air pressure regulators were fitted into the top of the simulators to control airflow and to apply air pressure to increase rainfall rates. A porous polyethylene material was secured to the bottom of the Plexiglas box using silicone adhesive caulk. This system generated a measured amount of simulated rainfall that flowed through the porous bottom of the rainfall simulator onto the test soil.

After filling the lysimeters with the contaminated soil, the lysimeter cells were saturated with RO water supplied from a 60-L polyethylene container. One end of a long piece of silicone tubing was attached to the dispensing outlet of the bottle, and the opposite end was connected to the leachate exit tube at the bottom of each lysimeter. Silicone tubing attached to an air pressure pump was fitted with a female quick-connect valve. A male quickconnect valve was placed in a large one-holed silicone stopper and the stopper was placed in the top of the bottle. The bottle was then placed on a tall mobile stand and positioned over each lysimeter. Approximately 45-L of water was allowed to saturate each lysimeter in an upward flow through all of the lysimeter cell layers (pea gravel, sand, and soil). The hydraulic head used for delivery of the saturation water was $1.5 \mathrm{~m}$.

In this study, a simulated rainfall amount was used that replicated the total average annual rainfall at the base in the Southeastern USA. In order to simulate this amount of rainfall in 16 weeks, 46.3-L $(7.47 \mathrm{~cm})$ of RO water was applied to each lysimeter each week. Approximately 45 -min were required to apply the total amount of RO water to each cell.

\subsection{Analytical methods}

Chemical and physical analytical procedures were used to establish the initial soil characterization and experimental results, including, specific gravity, particle-size distribution, and soil classification, determined according to procedures from the American Society for Testing and Materials (ASTM) D-854, D-422, and D-2487, respectively [30]; explosives concentrations by US EPA SW-846 Method 8330; digested metals by US EPA SW-846 Methods 3051 and 3015 [31]; Toxicity Characteristic Leaching Procedure, TCLP, (US EPA SW-846 Method 1311) [31]; distilled de-ionized water suspend and settle, DDI S\&S, (US EPA SW-846 Method 1311, ASTM D-3987-85) [30,31]; TOC; pH, and CEC (US EPA SW-846 Method 9081) [30,31]. The CEC was determined using US EPA SW-846 Method 9081; where soils are mixed with an excess of sodium acetate solution, washed with isopropyl alcohol, then ammonium acetate is used to exchange the sodium acetate from the soil and the samples were measured on a Thermal Jarrell Ash 61E trace ICP.

Leachate and runoff water samples were analyzed for total metals, dissolved metals, and explosives concentrations. Samples of leachate and runoff water were analyzed for dissolved metals after filtering through a $0.45-\mu \mathrm{m}$ filter following the procedures 
Table 2

Initial characterization of the native soil from the HGR in the Southeastern USA.

\begin{tabular}{lc}
\hline Soil property & HGR soil \\
\hline Specific gravity & 2.62 \\
Gravel (\%) & 0.50 \\
Sand (\%) & 77.2 \\
Fines (\%) & 22.3 \\
& \\
Soil classification & Silty sand (SM) \\
\hline TOC (\%) & 1.24 \\
CEC (mequiv./100 g) & 6.5 \\
pH & 5.5 \\
\hline
\end{tabular}

established in Method 3010 [32]. Filtered and total digest leachate samples were analyzed for 11 metals ( $\mathrm{Zn}, \mathrm{Fe}, \mathrm{Mn}, \mathrm{Ca}, \mathrm{Pb}, \mathrm{Cr}, \mathrm{Cu}, \mathrm{Ni}$, $\mathrm{Mb}, \mathrm{V}$, and $\mathrm{Sb}$ ) associated with munitions constituents using EPA SW-846 Method 6010 for Inductively Coupled Plasma (ICP) [31] analysis on a Perkins Elmer Optima 3000 or by SW-846 Method 6020 [32] ICP Mass Spectrometry (MS) using a Perkins Elmer Sciex 6000. Explosives (liquid phase samples) were analyzed by highperformance liquid chromatography (HPLC) following filtering of the samples to remove large particles. Solid phase extraction (SPE) was used to concentrate the RDX from the collected samples. Pre-packaged cartridges of Propak (Sep-Pak, $6 \mathrm{~cm}^{3}, 500 \mathrm{mg}$ ) from Waters Corporation were used for the SPE procedure according to the manufacturers' instructions. The TOC levels were determined using a Zellweger Astro Lab TOC Analyzer Model 2100 following manufacturers instructions. Statistical analysis was performed on lysimeter study data using SigmaPlot version 10 and SigmaStat version 3.5 (Systat Software, Inc.).

\section{Results and discussion}

The addition of lime as a soil amendment is commonly used in the agriculture community to assist in soil conditioning. The results from the treatability study indicate that the addition of lime enhances the degradation and stabilization of munitions constituents such as energetic compounds and metals. Characterization of soils and determination of the appropriate amount of lime to add to the soil is an important step in the treatment process.

\subsection{Soil characterization}

The initial physical and chemical characteristics of the HGR soil are detailed in Table 2. As seen in Table 2, the HGR soil is primarily composed of sand, $77 \%$, and the CEC is considered low at 6.5 mequiv./100 g. The low CEC in the soil indicates that there is less of a tendency for metals and organics to interact and potentially sorb to the soil. Nine sub-samples of the bulk homogenized soils were used for the initial metals analysis (Table 3 ). The initial RDX concentration was $2.38 \mathrm{mg} / \mathrm{kg}$ (Table 1 ).

\subsection{Determination of the lime amendment}

The native HGR soil was tested using ASTM 6276 [33] as modified by Davis et al. [34] in order to determine the appropriate lime dosage required to bring the study soil above $\mathrm{pH} 11.5$. This $\mathrm{pH}$ is necessary to provide both explosives transformation and metal immobilization. The HGR soil required a $1.0 \%$ lime application or $1.0 \mathrm{~g}$ hydrated lime per $100 \mathrm{~g}$ of soil.

\subsection{Column study}

A total of 1.12-L of RO water, $\mathrm{pH}$ 6.6, the equivalent of one year of rainfall based on the column diameter, was passed through the series of columns ( $45.72 \mathrm{~cm}$ of soil). The first column was HGR soil
Table 3

Initial metals concentrations $(\mathrm{mg} / \mathrm{kg}$ ) of homogenized background and HGR native soils $(n=9)$.

\begin{tabular}{|c|c|c|c|c|c|c|}
\hline \multirow[t]{2}{*}{ Metal } & \multicolumn{3}{|c|}{ Background soil } & \multicolumn{3}{|l|}{ HGR soil } \\
\hline & Avg & SD & \%RSD & Avg & SD & $\% \mathrm{RSD}$ \\
\hline $\mathrm{Sb}$ & $<1$ & na & na & $<1$ & na & na \\
\hline $\mathrm{Ca}$ & 26.24 & 4.28 & 16.32 & 74.52 & 16.10 & 21.60 \\
\hline $\mathrm{Cr}$ & 6.12 & 0.63 & 10.22 & 25.38 & 1.36 & 5.37 \\
\hline $\mathrm{Cu}$ & 1.35 & 0.09 & 6.70 & 17.37 & 3.51 & 20.22 \\
\hline $\mathrm{Fe}$ & 5547.67 & 58.18 & 1.05 & 9760.89 & 918.91 & 9.41 \\
\hline $\mathrm{Pb}$ & 4.61 & 0.14 & 3.09 & 32.71 & 11.34 & 34.66 \\
\hline $\mathrm{Mn}$ & 27.36 & 0.41 & 1.48 & 24.06 & 3.54 & 14.72 \\
\hline Mo & 0.40 & 0.06 & 14.89 & 1.26 & 0.17 & 13.76 \\
\hline $\mathrm{Ni}$ & 2.96 & 0.12 & 3.95 & 16.19 & 0.66 & 4.10 \\
\hline V & 5.48 & 0.03 & 0.53 & 23.66 & 1.32 & 5.56 \\
\hline $\mathrm{Zn}$ & 43.49 & 0.76 & 1.76 & 933.83 & 137.74 & 14.75 \\
\hline
\end{tabular}

na $=$ not applicable.

mixed with $1 \%$ (w:w) hydrated lime over native, untreated soil. There was a gradual increase in $\mathrm{pH}$ to a high of 12.1 in leachate passing through the first $15.24 \mathrm{~cm}$ of soil. The 2 nd and $3 \mathrm{rd}$ columns were packed with untreated native soil ( $\mathrm{pH}$ 5.5). The maximum and minimum leachate $\mathrm{pH}$ of these columns was significantly lower than those observed for the leachate from the limed Column 1 (Table 4). The column study results indicate, first, that the $\mathrm{pH}$ level of the surface soil had been raised to the treatment levels by the lime addition. Second, in moving through the soil, the leachate was neutralized by a combination of:

- contact with the buffer present in the native soil (Columns 2 and $3)$,

- hydroxide consumption in such reactions as explosives transformation and metals immobilization, and

- natural regeneration of soil buffering capacity in the limed soil over time.

As a result of the capability of the native soil to reduce the $\mathrm{pH}$ leaving the limed soil to neutral $\mathrm{pH}$, the leachate $\mathrm{pH}$ should have no adverse effects on groundwater beneath the range provided a significant layer of un-limed soil is retained beneath the impact area.

Table 4

Change in leachate $\mathrm{pH}$ recorded in the column study following treatment with hydrated lime on the surface of Column 1 soil and flushing with the equivalent of 1-year rainfall.

\begin{tabular}{lcll}
\hline \multirow{2}{*}{ Wetting event (daily) } & \multicolumn{2}{l}{ Leachate $\mathrm{pH}$} & \\
\cline { 2 - 4 } & Column 1 & Column 2 & Column 3 \\
\hline Native soil pH & 5.48 & & \\
1 & 6.08 & 5.76 & 6.82 \\
2 & 6.80 & 6.70 & 6.74 \\
3 & 8.68 & 6.60 & 5.18 \\
4 & 9.81 & 6.85 & 6.34 \\
5 & 11.36 & 6.96 & 6.41 \\
6 & 11.94 & 5.88 & 5.03 \\
7 & 12.11 & 5.95 & 6.19 \\
8 & 12.14 & 6.20 & 6.35 \\
9 & 11.84 & 6.17 & 6.55 \\
10 & 11.24 & 6.70 & 5.49 \\
11 & 11.63 & 6.67 & 5.70 \\
12 & 8.07 & 5.91 & 5.79 \\
Range & & & \\
$\quad$ Minimum & 6.08 & 5.76 & 5.18 \\
Maximum & 12.14 & 6.96 & 6.82 \\
\hline
\end{tabular}


Table 5

Sum of the mass of soluble RDX in lysimeter leachate and runoff water and reduction (\%) from the untreated control.

\begin{tabular}{lllll}
\hline $\begin{array}{l}\text { Lysimeter } \\
\text { treatment }\end{array}$ & $\begin{array}{l}\text { Mass leachate } \\
\mathrm{RDX}^{\mathrm{a}}(\mathrm{mg})\end{array}$ & $\begin{array}{l}\text { Leachate \% } \\
\text { reduction }\end{array}$ & $\begin{array}{l}\text { Mass runoff } \\
\mathrm{RDX}^{\mathrm{a}}(\mathrm{mg})\end{array}$ & $\begin{array}{l}\text { Runoff \% } \\
\text { reduction }\end{array}$ \\
\hline Control & 63.14 & na & 4.61 & na \\
$0.50 \%$ lime & 6.57 & 89.59 & 3.42 & 26 \\
$1.00 \%$ lime & 6.05 & 90.42 & 4.91 & na \\
$2.00 \%$ lime & 4.79 & 92.41 & 3.53 & 23 \\
\hline
\end{tabular}

na $=$ not applicable.

a Total mass based on concentration of RDX in leachate (runoff) and the volume of leachate (runoff) collected per rain event over 16 rain events.

\subsection{Lysimeter study: explosives transformation}

The effect of lime dosing on the soluble RDX leaving the HGR lysimeters as either leachate or runoff water is shown in Table 5. The range soil limed at $1 \%$ and $2 \%(\mathrm{w}: \mathrm{w}$ ) achieved greater than $90 \%$ reduction in soluble RDX in the leachate (compared to the untreated control). At the $2 \%$ lime treatment, runoff water only achieved $23 \%$ reduction in soluble RDX. Although TNT makes up 39\% of the high explosive in each grenade thrown, very little, to no detectable concentration of TNT found in the initial range soil samples prior to treatment with lime; so there was essentially non-detect concentration of TNT in the HGR soil that was initially collected.

The effect of lime dose on the total soluble RDX metabolites, MNX, DNX, and TNX, leaving the lysimeters as either leachate or runoff water is detailed in Table 6 . The leachate concentrations were generally more responsive to the lime dose than the surface water concentration, which is expected given the longer contact time with the hydroxide ion in the leachate. Leachate MNX increased with the 0.5 and $1 \%$ lime dose $(\mathrm{pH})$, but at the highest lime dose, $2 \%$, showed a $62 \%$ reduction from the control value. The DNX and TNX concentrations in the leachate were decreased in all of the limed systems, compared to the untreated control. Leachate DNX was reduced from 90 to $99 \%$ relative to the control; leachate TNX by 56 to $69 \%$. The response for both compounds was seen at the lowest lime dose but did not change significantly with greater changes in the $\mathrm{pH}$.

Surface water concentrations were much lower for all three metabolites regardless of the presence of hydrated lime. Reductions from the control values were seen in MNX and DNX concentrations beginning at the lowest lime dose. No reductions were seen in TNX surface water concentrations in any of the treatments. Total DNX losses from the system ranged from 85 to $92 \%$ of the control. TNX losses remained around 56\% of the control regardless of the treatment.

The RDX metabolites are known intermediates in the abiotic degradation pathway, particularly in the presence of iron and iron oxides $[35,36]$. When the iron compounds are absent, very little

Table 6

Average loss of soluble RDX metabolites by transport in leachate and surface water over all rain events $(n=16)$.

\begin{tabular}{llrll}
\hline Mass $(\mathrm{mg})$ & Control & \multicolumn{1}{l}{ 0.5\% lime } & \multicolumn{1}{l}{ 1\% lime } & 2\% lime \\
\hline MNX & & & & \\
$\quad$ Leachate & $0.82 \pm 0.101$ & $1.47 \pm 0.197$ & $1.01 \pm 0.137$ & $0.31 \pm 0.040$ \\
$\quad$ Surface water & $0.02 \pm 0.002$ & $0.004 \pm 0.001$ & $0.02 \pm 0.003$ & nd \\
$\quad$ Total & $0.84 \pm 0.103$ & $1.47 \pm 0.198$ & $1.04 \pm 0.140$ & $0.31 \pm 0.040$ \\
DNX & & & & \\
$\quad$ Leachate & $2.68 \pm 0.273$ & $0.14 \pm 0.026$ & $0.27 \pm 0.032$ & $0.03 \pm 0.005$ \\
$\quad$ Surface water & $0.32 \pm 0.029$ & $0.04 \pm 0.004$ & $0.06 \pm 0.006$ & $0.26 \pm 0.053$ \\
$\quad$ Total & $2.30 \pm 0.302$ & $0.18 \pm 0.030$ & $0.33 \pm 0.038$ & $0.29 \pm 0.058$ \\
TNX & & & & \\
$\quad$ Leachate & $0.48 \pm 0.063$ & $0.20 \pm 0.017$ & $0.15 \pm 0.012$ & $0.21 \pm 0.016$ \\
$\quad$ Surface water & $0.02 \pm 0.002$ & $0.03 \pm 0.002$ & $0.03 \pm 0.003$ & $0.03 \pm 0.003$ \\
$\quad$ Total & $0.50 \pm 0.065$ & $0.22 \pm 0.019$ & $0.18 \pm 0.014$ & $0.24 \pm 0.019$ \\
\hline
\end{tabular}

nd $=$ non-detect.
Table 7

Total suspended solids (TSS, mg) and the summed masses (mg) of those metals consistently found above the reporting limit in the lysimeter leachate and runoff water.

\begin{tabular}{llcrrr}
\hline \multirow{2}{*}{ Sample } & Water source & \multicolumn{2}{l}{ Mass $(\mathrm{mg})$ by treatment } & \\
\cline { 3 - 6 } & & Control & $0.5 \%$ lime & $1 \%$ lime & 2\% lime \\
\hline \multirow{2}{*}{ TSS } & Leachate & 283 & 215 & 264 & 249 \\
& Runoff & 945 & 644 & 715 & 373 \\
Zn & Leachate & 115 & $<30$ & $<20$ & $<22$ \\
& Runoff & 571 & 376 & 393 & 196 \\
$\mathrm{Fe}$ & Leachate & 539 & $<498$ & $<420$ & $<309$ \\
& Runoff & 1746 & 1303 & 1458 & 610 \\
$\mathrm{Mn}$ & Leachate & $<27$ & $<27$ & $<29$ & $<27$ \\
& Runoff & $<17$ & $<16$ & $<17$ & $<17$ \\
$\mathrm{Ca}$ & Leachate & 1899 & 23,449 & 28,410 & 52,641 \\
& Runoff & $<107$ & 789 & 2403 & 2879 \\
\hline
\end{tabular}

of the intermediates are detected, even in a reducing environment [37]. The soil involved in the treatability testing has an iron concentration of $9760 \mathrm{mg} / \mathrm{kg}$. This falls between the United States mean concentration of $18,000 \mathrm{mg} / \mathrm{kg}$ [38] and the range in the Eastern United States of $2000-550,000 \mathrm{mg} / \mathrm{kg}$ [39]. It is possible that the hydroxide ion from the lime amendment combined with the ferrous iron in the soil, promoting RDX degradation, with the resulting appearance of the MNX, DNX, and TNX.

\subsection{Lysimeter study: metals immobilization}

The hand grenade shell consists primarily of Fe, $\mathrm{Zn}$, and other trace metals. A total digest analysis was performed to determine the total metals being transported from the lysimeters in leachate and runoff water along with the mass of total suspended solids (TSS) (Table 7). Of the 11 metals analyzed, only 3 (Zn, Fe, and Mn) displayed consistent concentrations above the laboratory reporting limit (RL) of $0.050 \mathrm{mg} / \mathrm{L}$. Digested $\mathrm{Pb}$ concentrations were determined to be greater than the RL only during the first few rain events, and then fell below that RL. In general, the total mass of metals in the runoff from the control lysimeter were significantly more than from the treated lysimeters, with the exception of the expected increase in Ca from the treated cells.

Calcium was analyzed to track the presence of the hydrated lime that was added to the lysimeter cells. The soil lysimeters demonstrated increasing Ca leaching with increased lime amendment, as expected. The low Ca concentrations in the HGR leachate were attributed to the reaction of the lime with either metals in the pore-water solution or other minerals capable of consuming the hydroxide ion and producing mobile $\mathrm{Ca}^{2+}$. Calcium sinks in the lysimeter cells may also include the precipitation of the carbonate compounds (calcium and magnesium bicarbonate) as calcium carbonate $\left(\mathrm{CaCO}_{3}\right)[40]$.

The mass of TSS was included because suspended solids can be indicative of metals loss in particulate form or of metals bound to suspended solids [7]; however, the trends in TSS levels with liming dose were statistically inconclusive for the $0.5 \%$ and $1.0 \%$ liming cells. The mass of TSS in the runoff water was decreased significantly compared to the control at the highest lime dose (2\%) and was significantly correlated with loss of $\mathrm{Zn}$ and Fe.

The decrease in metal concentration in leachate and runoff compared to the untreated control is shown in Table 8 . These are conservative calculations in that the laboratory reporting limit $(0.05 \mathrm{mg} / \mathrm{L})$ was always used in place of a value below detection limits. Reductions were greater in the leachates than in the runoff water, probably due to the extended contact time of the leachates with the high $\mathrm{pH}$ area. Zinc, the predominant metal found in the HGR soils, was reduced by $83 \%$ in the leachate with a $1 \%$ addition of lime. This value was similar in the $2 \%$ lime addition, with 
Table 8

Decrease in concentration (\%) of TSS and metals from control values by treatment.

\begin{tabular}{lllll}
\hline \multirow{2}{*}{ Sample } & Water source & \multicolumn{2}{l}{ Decrease in concentration from control (\%) } \\
\cline { 3 - 5 } & & $0.5 \%$ lime & $1 \%$ lime & 2\% lime \\
\hline \multirow{2}{*}{ TSS } & Leachate & 24.03 & 6.71 & 12.01 \\
& Runoff & 31.85 & 24.34 & 60.53 \\
$\mathrm{Zn}$ & Leachate & 73.91 & 82.61 & 80.87 \\
& Runoff & 34.15 & 31.17 & 65.67 \\
$\mathrm{Fe}$ & Leachate & 7.61 & 22.08 & 42.67 \\
\multirow{2}{*}{$\mathrm{Mn}$} & Runoff & 25.37 & 16.49 & 65.06 \\
& Leachate & $\mathrm{NC}$ & $\mathrm{NC}$ & $\mathrm{NC}$ \\
& Runoff & $\mathrm{NC}$ & $\mathrm{NC}$ & $\mathrm{NC}$ \\
\hline
\end{tabular}

$\mathrm{NC}=$ no change.

added reduction in the runoff water (66\%). The $2 \%$ lime addition also resulted in significant reductions in the TSS in the runoff water. The lime amendment had no effect on the concentration of Mn in either leachate or runoff water as most of these values were below the RL. The metals will form metal-hydroxides that should be sparingly insoluble and relatively stable in the environment; but there is the potential for these stable metal forms to migrate if there are changes in the local environment that make them less stable as metal-hydroxides. The addition of lime at the three doses of 0.5-, $1-$, and $2 \%$ showed positive results by decreasing TSS, Zn, and Fe in the leachate and runoff waters that were collected, but there are some trends that are seemingly not consistent with the increase in lime dose. The trends presented in Table 8 used the RL as a lower boundary when summing the total amount of TSS, Zn, Fe, and Mn in the leachate or runoff water, so there is some fluctuation due to the low values that were calculated.

\subsection{Lysimeter study $-\mathrm{pH}$}

Potential environmental effects of the lime amendment technology were evaluated by monitoring $\mathrm{pH}$ changes. For the treatment to effectively transform explosives and stabilize metals in the source zone areas (surface 15-cm) it is necessary to maintain the soil and leachate (pore water) $\mathrm{pH}$ over 10.5 in the soil volume close to the surface. To be protective of surface waters, the $\mathrm{pH}$ outside the source zone (runoff water) should, typically, be below 9.5.

\subsubsection{Soil $p H$}

During the 16-week lysimeter study, the $\mathrm{pH}$ of the untreated native soil remained relatively constant. At the conclusion of the study, the soil pH levels of the lysimeters treated with the highest concentration of lime remained above the treatment goal of $\mathrm{pH} 10.5$, indicating that lime application could be an effective best management technique for range management of munitions constituents.

\subsubsection{Leachate $\mathrm{pH}$}

Changes in lysimeter leachate $\mathrm{pH}$ over the course of the treatment are shown in Fig. 4A. These results demonstrate that lime application sufficient to treat the explosives residue in the surface soil can be achieved by surface treatment of the soil (i.e. top $15 \mathrm{~cm}$ ). To be protective of groundwater, the subsurface $\mathrm{pH}$ must return to neutral or to the $\mathrm{pH}$ of the native soil. This $\mathrm{pH}$ buffering process was also demonstrated in the column study referred to earlier.

\subsubsection{Runoff $p H$}

Changes in lysimeter surface water runoff $\mathrm{pH}$ over the course of the treatment are shown in Fig. 4B. The runoff water from the HGR lysimeters soils treated with 1 and $2 \%$ (w:w) lime averaged a $\mathrm{pH}$ of 9.6 and 9.7 respectively, just slightly above the target $\mathrm{pH}$ of 9.5 . Under natural conditions, runoff water chemistry is modified by the soil as it passes over, thus typically allowing the runoff to take on the soil's near-surface $\mathrm{pH}$ characteristics. These results indicate that, for the experimental conditions considered (e.g., rainfall rate, slope, soil conditions), lime application would not result in elevated pH levels in runoff water from treated areas, which otherwise might affect surface waters offsite.

\section{Conclusions}

The results from these studies indicate that the source zone soil $\mathrm{pH}$ can achieve the desired treatment $\mathrm{pH}$ level above 10.5 in this Southeastern USA HGR soil. This $\mathrm{pH}$ was sufficient to reduce the concentration of RDX in leachate by greater than $90 \%$ compared to the untreated control. RDX, TNT and their respective breakdown products can be of environmental concern, but the Alkaline Hydrolysis process was demonstrated to produce environmentally friendly end products [14,17]. Of the grenade metals analyzed, only $\mathrm{Zn}, \mathrm{Fe}$, and $\mathrm{Mn}$ were found consistently in the leachate and runoff water. The concentrations of $\mathrm{Zn}$ and $\mathrm{Fe}$ in runoff water and leachate were reduced even at the lowest lime dose. The mass of TSS in the runoff water was decreased significantly from the control at the highest lime dose (2\%) and was significantly correlated with loss of $\mathrm{Zn}$ and Fe. The metals will form metal-hydroxides that should be sparingly insoluble and relatively stable in the environment.

Using the liming technology, the $\mathrm{pH}$ levels of the runoff water, water that could potentially enter a surrounding watershed, can be held at, or below, 9.5. The leachate and runoff waters from these studies were collected directly from the source. The natural buffering that would occur between the leachate/runoff water and the native soils and, in the case of the runoff water, with the atmosphere, was not possible in this study. This buffering would further ameliorate the $\mathrm{pH}$. The $\mathrm{pH}$ of the water leaving the amended areas would also be decreased when it is mixed with surface and
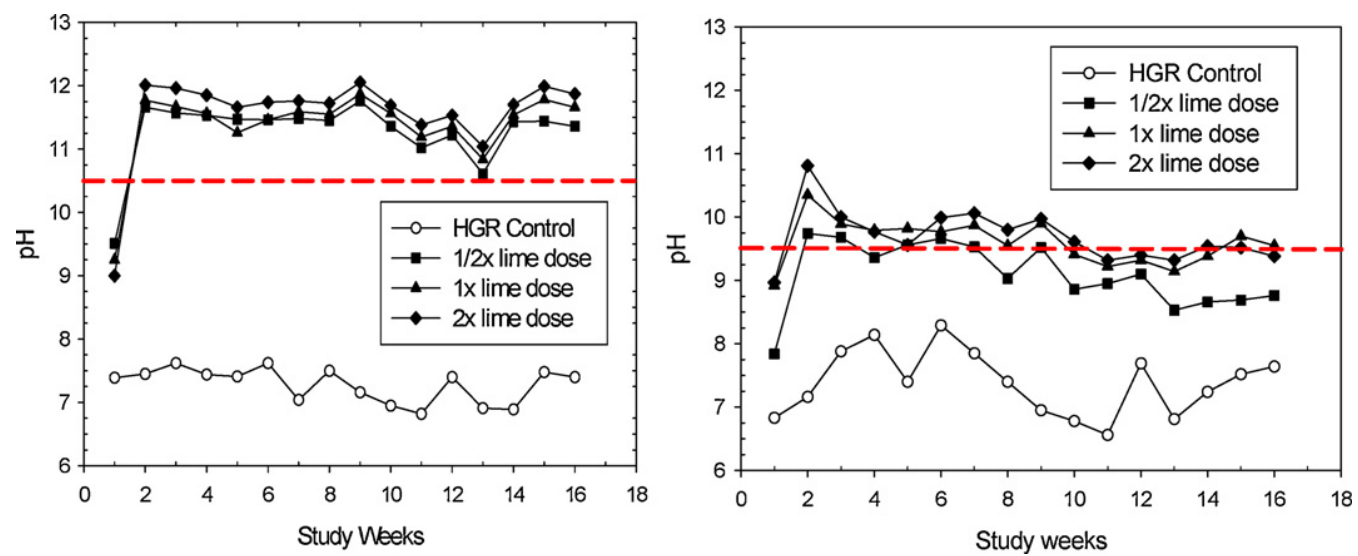

Fig. 4. Lysimeter $\mathrm{pH}$ measurements. (A) Weekly leachate $\mathrm{pH}$ with target $\mathrm{pH}$ (10.5) indicated. (B) Weekly runoff water $\mathrm{pH}$ with target $\mathrm{pH}$ (9.5) indicated. 
subsurface water from un-amended areas as demonstrated by the column study.

All of these factors suggest that lime addition is an effective best management practice and successful treatment for munitions constituents on grenade ranges and similar ranges. Adverse side effects, as outlined in this study, will be minimal with the proper scale up procedures.

\section{Acknowledgements}

This work was funded by the Environmental Security Technology Certification Program (ESTCP) as field demonstration project ER-0216. This project was awarded the ESTCP Project of the Year (2007). The authors wish to thank Ms. Beth-Anee Johnson, Integrated Training Area Management Office (ITAM). The gracious participation of the range control personnel for the assistance with obtaining range samples in support of this project is also acknowledged. Technical assistance was provided by Mr. Milton Beverly (Environmental Research and Development, Inc. - ERAD), Mr. Chris Griggs (ERDC-EL), Ms. Michelle Thompson (Applied Research Associates, Inc., currently with ERDC-EL), Ms. LeeAnn Riggs and Ms. Deborah Regan (SpecPro), Mr. Casey Trest (Mississippi State University), and Ms. Tarmiko Graham (Alcorn State University).

\section{References}

[1] T.F. Jenkins, A.D. Hewitt, C.L. Grant, S. Thiboutot, G. Ampleman, M.E. Walsh, T.A. Ranney, C.A. Ramsey, A.J. Palazzo, J.C. Pennington, Identity and distribution of residues of energetic compounds at army live-fire ranges, Chemosphere 63 (2006) 1280-1290.

[2] S.L. Larson, W.A. Martin, B.L. Escalon, M. Thompson, Dissolution, sorption, and kinetics involved in systems containing explosives, water, and soil, Environ. Sci. Technol. 42 (3) (2008) 786-792.

[3] T.F. Jenkins, J.C. Pennington, T.A. Ranney, T.E. Berry, Jr., P.H. Miyares, M.E. Walsh, A.D. Hewitt, M.N. Perron, L.V. Parker, C.A. Hayes, E.G. Wahlgren, Maj, Characterization of Explosives Contamination at Military Firing Ranges, ERDC/CRREL TR-01-5, U.S. Army Engineer Research and Development Center, Hanover, NH, 2001, http://libweb.wes.army.mil/uhtbin/hyperion/CRREL-TR-01-5.

[4] J.C. Pennington, T.F. Jenkins, J.M. Brannon, J. Lynch, T.A. Ranney, T.E. Berry, C.A. Hayes, P.H. Miyares, M.E. Walsh, A.D. Hewitt, N. Perron, J.J. Delfino, Distribution and Fate of Energetics on DoD Test and Training Ranges: Interim Report 1, ERDC/EL TR-01-13, U.S. Army Engineer Research and Development Center, Vicksburg, MS, 2001, http://libweb.wes.army.mil/uhtbin/hyperion/EL-TR-0113.

[5] J.C. Pennington, T.F. Jenkins, G. Ampleman, S. Thiboutot, J.M. Brannon, J. Lynch, T.A. Ranney, J.A. Stark, M.E. Walsh, J. Lewis, C.A. Hayes, J.E. Mirecki, A.D. Hewitt, N. Perron, D. Lambert, J. Clausen, J.J. Delfino, Distribution and Fate of Energetics on DoD Test and Training Ranges: Interim Report 2, ERDC/EL TR-02-08, U.S. Army Engineer Research and Development Center, Vicksburg, MS, 2002, http://libweb.wes.army.mil/uhtbin/hyperion/EL-TR-02-8.

[6] S.L. Larson, B. Tardy, M. Beverly, A. Hearn, M. Thompson, G. Williams, Topical Application of Phosphate Amendments to Lead-contaminated Small Arms Firing Range Soils, ERDC/EL TR-04-20, U.S. Army Engineer Research and Development Center, Vicksburg, MS, 2004, http://libweb.wes.army.mil/uhtbin/hyperion/EL-TR-04-20.

[7] S.L. Larson, B. Tardy, K. Rainwater, J. Tingle, Rainfall Lysimeter Evaluation of Leachability and Surface Transport of Heavy Metals from Six Soils With and Without Phosphate Amendment, ERDC/EL TR-05-9, U.S. Army Engineer Research and Development Center, Vicksburg, MS, 2005, http://libweb.wes.army.mil/uhtbin/hyperion/EL-TR-05-9.

[8] B.A. Tardy, R.M. Bricka, S.L. Larson, Chemical Stabilization of Lead in Small Arms Firing Range Soils, ERDC/EL TR-03-20, U.S. Army Engineer Research and Development Center, Vicksburg, MS, 2003, http://libweb.wes.army.mil/uhtbin/hyperion/EL-TR-03-20.

[9] S.L. Larson, P.G. Malone, C.A. Weiss, W.A. Martin, C. Trest, G. Fabian, M.F. Warminsky, D. Mackie, J.J. Tasca, J. Wildey, J. Wright, Amended Ballistic Sand Studies to Provide Low Maintenance Lead Containment at Active Small Arms Firing Range Systems, ERDC/EL TR-07-14, U.S. Army Engineer Research and Development Center, Vicksburg, MS, 2007a, http://libweb.wes.army.mil/uhtbin/hyperion/EL-TR-07-14.

[10] S.L. Larson, C.L. Teeter, V.F. Medina, W.A. Martin, Treatment and Management of Closed or Inactive Small Arms Firing Ranges, ERDC-EL TR-07-3, U.S. Army Engineer Research and Development Center, Vicksburg, MS, 2007b, http://libweb.wes.army.mil/uhtbin/hyperion/EL-TR-07-3.

[11] G. Fabian, K. Watts, Army Small Arms Training Range Environmental Best Management Practices (BMPs) Manual, SFIM-AEC-AT-CR-2006007, Aberdeen Proving Ground, MD, 2006.
[12] USEPA, Office of Prevention, Pesticides and Toxic Substances, Fate, Transport and Transformation Test Guidelines, Hydrolysis as a Function of $\mathrm{pH}$ and Temperature, EPA 712-C-98-059, Washington, DC, 1998.

[13] National Research Council, Review and Evaluation of Alternative Technologies for Demilitarization of Assembled Chemical Weapons, National Academy Press, Washington, DC, 1999

[14] D.R. Felt, C.C. Nestler, J.L. Davis, S.L. Larson, Potential for Biodegradation of the Alkaline Hydrolysis End Products of TNT and RDX, ERDC/EL TR-07-25, U.S. Army Engineer Research and Development Center, Vicksburg, MS, 2007, http://libweb.wes.army.mil/uhtbin/hyperion/EL-TR-07-25.

[15] A.H.Wani, J.L. Davis, RDX biodegradation column study: influence of ubiquitous electron acceptors on anaerobic biotransformation of RDX, J. Chem. Technol. Biotechnol. 78 (2003) 1082-1092.

[16] A.H. Wani, D.R. Felt, J.L. Davis J.L., RDX biodegradation column study: extent of RDX mineralization and influence of temperature on rate of RDX biotransformation, Environ. Eng. Sci. 22 (2005) 310-323.

[17] M.C. Brooks, J.L. Davis, S.L. Larson, D.R. Felt, C.C. Nestler, Topical Lime Treatment for Containment of Source Zone Energetics Containment, ERDC/EL TR-03-19, U.S. Army Engineer Research and Development Center, Vicksburg, MS, 2003, http://libweb.wes.army.mil/uhtbin/hyperion/EL-TR-03-19.

[18] S. Waisner, V.F. Medina, A.B. Morrow, C.C. Nestler, Evaluation of chemical treatments for a mixed contaminant soil, J. Environ. Eng. 134 (2008) 743-749.

[19] L. Charerntanyarak, Heavy metals removal by chemical coagulation and precipitation, Water Sci. Technol. 39 (10/11) (1999) 35-138.

[20] T.A. Kurniawan, G.Y.S. Chan, W.-H. Lo, S. Babel, Physico-chemical treatment techniques for wastewater laden with heavy metals, Chem. Eng. J. 118 (2006) 83-98.

[21] M. Fang, J.W.C. Wong, Effects of lime amendment on availability of heavy metals and maturation in sewage sludge composting, Environ. Pollut. 06 (1999) 83-89.

[22] J.W.C. Wong, A. Selvam, Speciation of heavy metals during co-composting of sewage sludge with lime, Chemosphere 63 (2006) 980-986.

[23] J.D. Mckinley, H.R. Thomas, K.P. Williams, J.M. Reid, Chemical analysis of contaminated soil strengthened by the addition of lime, Eng. Geol. 60 (2001) 181-192.

[24] W. Geebelen, D.C. Adriano, D. van der Lelie, M. Mench, R. Carleer, H. Clijsters, J. Vangronsveldt, Selected bioavailability assays to test the efficacy of amendment-induced immobilization of lead in soils, Plant Soil 249 (1) (2003) 217-228.

[25] C.W. Gray, S.J. Dunham, P.G. Dennis, F.J. Zhao, S.P. McGrath, Field evaluation of in situ remediation of a heavy metal contaminated soil using lime and red-mud Environ. Pollut. 142 (2006) 530-539.

[26] J.O. Borthwick, E.A. Beshore, Sustaining DOD ranges: a national environmental challenge, Fed. Facil. Environ. J. (Summer) (2000) 17-25.

[27] Interstate Technology and Regulatory Council (ITRC), Small Arms Firing Range Team, Characterization and Remediation of Soils at Closed Small Arms Firing Ranges, 2003, Available online http://www.itrcweb.org/gd.asp.

[28] ITRC, Small Arms Firing Range Team, Environmental Management at Operating Outdoor Small Arms Firing Ranges, 2005, Available online: http://www.itrcweb.org/gd.asp.

[29] D.D. Jones, M. Messenger, R. Webster, R. Stine, Installation sustainability: transforming - the Army's future, Fed. Facil. Environ. J. 13 (1) (2002) 27-38.

[30] ASTM, Standard test methods D422, D854, and D2487, West Conshocken, PA, USA, 2001.

[31] U.S. Environmental Protection Agency (USEPA), Test Methods for Evaluating Solid Waste, Physical/Chemical Methods, SW-846, Washington, DC, 1999.

[32] American Public Health Association (APHA), in: A.D. Eaton, L.S. Clesceri, A.E. Greenberg, M.A.H. Franson (Eds.), Standard Methods for the Examination of Water and Wastewater, Method 3010, 20th ed., prepared and published jointly by American Public Health Association, American Water Works Association, Water Environment Federation, Washington, DC, 1998.

[33] American Society for Testing and Materials (ASTM), Standard Test Method for Using pH to Estimate the Soil-Lime Proportion Requirement for Soil Stabilization, Report D6276, West Conshocken, PA, USA, 1999.

[34] J.L. Davis, S.L. Larson, D.R. Felt, C.C. Nestler, L. Riggs, W.A. Martin, E. Valente, G.R. Bishop, Engineering Considerations for Hydroxide Treatment of Training Ranges, ERDC/EL TR-07-3, U.S. Army Engineer Research and Development Center, Vicksburg, MS, 2007, http://libweb.wes.army.mil/uhtbin/hyperion/ELTR-07-3.

[35] K.B. Gregory, P. Larese-Casanova, G.F. Parkin, M.M. Scherer, Abiotic transformation of hexahydro-1,3,5-trinitro-1,3,5-triazine by Fe ${ }^{\mathrm{II}}$ bound to magnetite, Environ. Sci. Technol. 38 (2004) 1408-1414.

[36] B.-T. Oh, C.L. Just, P.J. Alvarez, Hexahydro-1,3,5-trinitro-1,3,5-triazine mineralization by zero valent iron and mixed anaerobic cultures, Environ. Sci. Technol. 35 (2001) 4341-4346.

[37] A.H. Wani, B.R. O'Neal, D.M. Gilbert, D.B. Gent, J.L. Davis, Electrolytic transformation of ordnance related compounds (ORCs) in groundwater: laboratory mass balance studies, Chemosphere 62 (2006) 689-698.

[38] H.T. Shacklette, J.G. Boerngen, Element Concentrations in Soils and Other Surficial Materials of the Conterminous United States, U.S. Geological Survey Professional Paper 1270, 1984.

[39] M.J. O’Toole, Technical and Administrative Guidance Memorandum \#4046: Determination of Soil Cleanup Objectives and Cleanup Levels, New York State Department of Environmental Conservation, 1994.

[40] W. Viessman, M.J. Hammer, Water Supply and Pollution Control, 6th ed., Addison Wesley, Menlo Park, CA, 1998, pp. 438-450. 